\title{
THE SPECIAL NATURE OF THE INSURANCE CONTRACT: A FEW SUGGESTIONS FOR FURTHER STUDY
}

"What do they know of the law of the insurance contract who only the law of contract know?"**

Frankin M. Schultz†

John Doe picks up the phone and dials his insurance agent. "I just bought my wife a mink coat for our twenty-fifth anniversary," says Doe. "It set me back $\$ 3,500$. I'd like to insure it at full value."

"Sure," replies the agent, "I'll write it up on a floater right away and send you the policy. The premium will run about $\$ 64$." Several weeks later Doe receives the policy and a bill in the mail. He notes the policy is a "fur floater" and in the amount of $\$ 3,500$. He puts it in his strong box and writes out a check for the amount of the bill on the first of the month when he pays his other monthly bills.

If you were to ask Doe what he has done, he would probably say that he has "bought" some insurance. From whom has he bought it? His local agent-the one that handles his "general" insurance; another agent handles his life insurance. Does he know which company issued the policy? No, and he doesn't care. Does he question the amount of the premium? No-he understands that is "standard." Does he know whether his wife's coat is covered under all circumstances? No-he hasn't read the policy; he tried to read one once and fell asleep in the process; he assumes his agent took care of full coverage. Does he know how long the policy runs? No-he assumes three years; the agent always takes care of renewals and bills him as a matter of course. Has he signed any paper? No-he never does in these insurance deals unless it involves life insurance. Does he realize he has entered into an insurance contract? No-he has never thought of it in that way.

Now, if one were to ask what John Doe has done in the "eye of the law," the response would probably be: Doe has entered into a unilateral, aleatory contract, the consideration on his side being the payment of an insurance premium, the consideration on the other side being a promise to indemnify for a three year period in the event the mink coat disappears-subject to numerous conditions, as, for example, that Doe make proof of loss within sixty days, cooperate with the insurer in recovering the property, bring any action against the insurer within two years, etc. Should Doe fail to comply with any of these conditions précedent or subsequent, as the case may be, he cannot recover from the insurer.

- Edwin H. Woodruff, Selection of Cases on the Law of Insurance 5 (2d ed. 1924).

† A.B. 1939, LI.B. 1942, Yale University. Assistant Professor of Law, Indiana University School of Law. Member of the Ohio Bar. 
There are at least two points to make about the "lay" as compared with the "law" reaction to this simple business transaction. One is that "language-wise" they are poles apart. Doe is speaking of having "bought" something, which he may call "protection" or "coverage"; the law speaks of his having entered, through bargaining and negotiation, a "contract"- a consensual, continuing relationship. Second, the legal term-unilateral, aleatory contract-which the "law" uses to classify Doe's transaction embraces many other commercial and non-commercial transactions. Doe, for example, would have entered into a unilateral, aleatory contract if he had given a prospector \$100 to stake out a claim in Alaska in return for the prospector's promise of $\$$ ro,00o if the grubstake turned out to be a bonanza. Yet, traditionally in both the insurance and grubstake transactions, the contractual presuppositions are the same: each party knew with whom he was dealing; each bargained, haggled, or dickered over the consideration to be received; each knew exactly what he was receiving in return for what he gave (a premium or cash for a promise of cash in the future on the happening of a contingency-loss of a mink coat or "striking it rich"); and finally, each assented to the "bargain" in every respect, i.e., there was a "meeting of the minds." Crane, J., speaking for the New York Court of Appeals, summarizes the traditional view thus: "A contract for insurance is no different than any other contract. The insurance company is entitled to have its contract enforced by the courts as written."1 But one need only run through modern legal literature to discover that there has long been a strong dissent from the traditional tendency to lump insurance contracts with other contracts. Burch, J., speaking for the Kansas Supreme Court, was among the first to strike this dissident note. "The subject, therefore, is sui generis, and the rules of a legal system devised to govern the formation of ordinary contracts between man and man cannot be mechanically applied to it." If one were to paraphrase Judge Burch's phrase "sui generis" in modern terms, it might read: Insurance protection, first, is a necessity, in almost a class with everyday utilities such as water, gas, and light. As in the case of utilities, neither the price nor other terms are bargained for. Embodied in a printed, standardized, mass-produced form, drawn up by the insurer's lawyers, and presented to the buyer as a finished product, insurance is one of the few complicated legal transactions a layman enters into without a lawyer at his elbow. It is undoubtedly as detailed and complex as a contract for the sale of land, a deed, or a will, none of which a careful layman would undertake to negotiate without benefit of counsel. Moreover, the insured deals directly with an agent and is seldom concerned about the identity of the principal (except in life insurance). Once received by the insured, the policy is seldom read, almost never fully understood. In a word, an insurance transaction is a one-sided "bargain"; if it merits the label "contract," it is in a very specialized, not an ordinary, sense.

${ }^{1}$ Drilling v. New York Life Ins. Co., 234 N. Y. 234, 241, r37 N. E. 314, 316 (1922).

2 Pfiester v. Missouri State Life Ins. Co., 85 Kan. 97, 102, I I6 Pac. 245, 247 (r91 r). I am indebted w Dcan Havighurst for pointing out the juxtaposition of this opinion with the Drilling case, stpra note $\mathrm{r}$, in George W. Goble, Cases and Other Materials on the Law of Instirance 872, 876 (2d ed. 1949). 
'It is not the purpose of this article to examine the validity of such a modern definition of the typical insurance transaction by means of an exhaustive study, but rather to inquire whether recent developments in insurance law justify some such study and, if so, to suggest some possible avenues for investigation.

\section{Construction of Insurance Contracts in General}

Despite Justice Holmes's sweeping statement that "no rational theory of contract can be made that does not hold the assured to know the contents of the instrument to which he seeks to hold the other party," ${ }^{3}$ and the Restatement's black letter rule binding a party who should have "reasonably" understood an offer or proposed contract, "though ignorant of the terms of the writing or of its proper interpretation," all the king's horses and all the king's men have been unable to hold together this principle-the so-called objective theory of contracts-as it relates to insurance agreements. Long ago Professor Vance, one of the great experts in insurance law, asserted that the public at large and some courts acknowledged "the pre'vailing business custom" of "even careful business men" not to read their policies but to rely on "the accuracy, skill and good faith of the agent." Williston in his monumental treatise on contracts also acknowledges the large number of decisions which can be explained only by the "well-recognized, though negligent, practice of most purchasers of insurance not to read their policies, but to rely on the agent's good faith and skill."

In fact, the improbability that the ordinary insurance buyer will read his policy has led to practical abandonment of the parol evidence rule in insurance cases on the ground that it is unrealistic to speak of "integration" where there is no true bargain or acceptance. ${ }^{7}$ Similarly, the cases are legion where, the insured having relied on the unauthorized oral representation of the insurer's agent, the familiar waiver, estoppel, and reformation devices have been used to overcome the failure of the insured to note that the contents of the policy differed from the agent's representation. $^{8}$

Moreover, although many judges pay lip-service to the proposition that an insurance contract should be construed as any other contract, the real purpose of the construction being to give full effect to the expressed intention of the parties, ${ }^{9}$ it is a matter of common knowledge that where any doubt or ambiguity exists in an insurance policy it will be resolved against the draftsman, i.e., the insurance company.

\footnotetext{
${ }^{3}$ Lumber Underwriters of New York v. Rife, 237 U. S. 605, 609 (1915).

- Restatement, Contracts $\$ 70$ (1932).

- Williakr R. Vance, Handbook of the Law of Insuranice 215 (2d ed. 1930).

${ }^{\circ}$ Samuel Williston, A Treatise on the Law of Contracts $\$ 751$ (rev. ed., Williston and Thompson, 1936$)$.

'See Note, 47 Harv. L. Rev. roro (r934).

- S See Note, 62 Harv. L. Rev. 87 (1948); Comment, 35 Yale L. J. 203 (1925).

- VANCE, Op. cit. stipra note 5, at 689-690. 
This so-called rule of strict construction is the hallmark of a "contract of adhesion"10 of which insurance is the classic example. The premise is that the insurance contract is drawn up by the insurance company, which, staffed with expert legal counsel, has drafted the policy to serve its best interests and that the insured, who-usually without the benefit of any counsel-merely "adheres" to it, has little choice as to its terms. ${ }^{11}$ Consequently, the company must pay the penalty for any ambiguity it unluckily creates in the process. Worse still, from the company's point of view at least, is the tendenicy of the courts to "discover" such ambiguities. Take New York Life Insurance Co. $v$. Hiatt, ${ }^{12}$ for example. The question was whether a beneficiary could recover double indemnity on a life insurance policy when the insured's death resulted from the inhalation of carbon monoxide, one of the nine causes excepted from the double indemnity rider. In mistaken compliance with a California statute requiring a brief description to be printed on the first page and the filing back of the policy, the company had stamped on the cover page in purple ink: "Double Indemnity for Fatal Accident." This was its undoing. The ninth circuit affirmed the district judge's conclusion that the stamped writing superseded the printed rider, saying: $:^{13}$

... to the lay mind the phrase represents the concise expression of a readily comprehensible thought. The average layman knows what double indemnity means and he has a pretty fair notion of what a fatal accident is. To him the term comprehends all forms of death suffered accidentally. Not inconceivably, the presence of the stamped matter was the decisive factor in effecting the sale of the policy.

There was no evidence of any reliance by the insured on the stamped matter or on any related representation by the soliciting agent or the company's advertising matter. Yet a unanimous court thought that even if the insured had read the whole instrument, it would probably leave in his "uninitiated mind the belief that the specially stamped phraseology was intended to afford a measure of protection broader than that indicated in the printed language of the rider."14

Sic semper the insurer. You may not be able to tell a book by its cover, unless it's an insurance policy-and you are the beneficiary.

One would expect this one-way street, the strict construction canon, to have passed into oblivion once the statutory insurance form had entered the stage. If the legislature prescribes a standard form of policy or standard provisions to be incorporated, or the insurance commissioner has approved a company form, it can hardly be said the policy was "drafted" solely by the company. ${ }^{15}$ As a matter of fact, since such

\footnotetext{
10 Pattcrson, in The Delivery of A Life-Insurance Policy, 33 HARv. L. REv. 198, 222 (1919), first introduced the term from the French law into our vocabulary.

${ }^{21}$ lbid.

12 140 F. 2d 752 (9th Cir. 1944). $\quad{ }^{13} I d$. at 753.

${ }^{14}$ Ibid.; cf. Northern Trust Co. v. The Central Life Ins. Co., 274 Ill. App. 55 I (1934).

${ }^{15}$ Some courts have abandoned the strict construction rule in this instance. See, e.g., Wilcox v. Massachusetts Protective Ass'n, 266 Mass. 230, I65 N. E. 429 (1929); Rosenthal v. Insurance Co. of North America, 158 Wis. 550, 149 N. W. 155 (1914); Gallopin v. Continental Casualty Co., 290 Ill. App. 8, 7 N. E. $2 d 771$ (1937).
} 
policy provisions are presumably drafted by the state agencies, representing all the policyholders, logically, the language should be construed against the insured rather than the company. ${ }^{16}$ But the logic of this argument fails to square with the case results. In the main the courts still reach judgment for plaintiff by construing the standard policies against the company, just as if they were still drafted by the company. ${ }^{17}$

The judicial rationales make interesting reading. As early as igII, a North Carolina court, quoting Professor Vance, stated that since the "terms of these statutory policies were chosen with reference to the construction given by the precedent cases to similar terms in other policies, and, therefore, ought to be regarded as being used in the sense of their previous construction, ${ }^{18}$ there was no reason to abandon the strict construction rule. The court also explained that the statutory terms were really chosen by the underwriters with particular reference to their own interests, and hence should be construed strictly against them as the real villains of the piece. Such a charge could be well substantiated as to the 1886 standard fire policy, which was prepared exclusively by the New York Board of Fire Underwriters (a private insurance group), ${ }^{19}$ but could hardly be supported as to the latest 1943 standard policy. ${ }^{20} \mathrm{~A}$ recent North Carolina court has added this rationale: "The rights of the parties after the policy has been issued must be ascertained and determined in accordance with the terms and provisions of the contract and derive no extra validity by reason of the fact that the form is prescribed by law."21 In other words, even though the form of the policy is legislatively prescribed, the insurance contract still derives its validity from the "consent" of the parties.2

Logic, it seems, particularly as related to the contract canons of construction, finds little support in the insurance literature.

\section{II}

\section{The Life Cycle of a Life Insurance Contract}

In addition to the study of the peculiar rules of construction just noted, another way to determine whether modern judges recognize the uniqueness of the insurance contract is to examine in terms of recent litigation several phases in the life

${ }^{13}$ See Calhoun, The Liberal Construction of Insurance Contracts, I Cons. BAR J. 49, 50 (1927).

${ }^{17}$ VANCE, op. cit. supra note 5, at $69 \mathrm{r}$.

${ }^{18}$ Gazzam v. German Union Fire Ins. Co., 155 N. C. 330, 338-339, 71 S. E. 434, 438 (1911).

${ }^{19}$ Edwin W. Patterson, The Insurance Commissioner in The United States 249 (1927).

${ }^{20}$ Patterson, Insturance Law During the War Years, 46 CoL. L. REv. 345, 347 (1946).

${ }^{21}$ Atlantic Joint Stock Land Bank of Raleigh v. Foster, 217 N. C. 415, 419, 8 S. E. 2d 235, 237 (1940).

${ }^{2}$ It has also been suggested that "even a statute adopted for the purpose of avoiding the equivocalities of company-drafted policies may be ambiguous. In such a situation, public policy may similarly require construction against the insurer, by predicating it not upon the drafter's fault, but upon the risk-sharing purpose of insurance." 44 CoL. L. REv. $766,770-77$ I (1944). It is a little difficult to see how the insurers could share the risk of "ambiguities" in the statutory form unless they could pre-estimate the cost of litigation and judgments resulting from discoverable ambiguities and increase the premium rates accordingly. 
history of an insurance contract. For this purpose the life insurance transaction is probably better laboratory material than fire, casualty, or some other type of insurance. From the average individual's point of view, life is the keystone of insurance protection; it represents not only the sole security but the bulk of total savings and most acceptable loan collateral of the vast majority of people. As compared with fire and casualty, it also comes closer, though not very close, to the classical bargained-for contractual transaction. At least, between the first approach of the life agent ("no one has endurance like the man who sells insurance") and the delivery of the policy there is a waiting period which may suggest the possibility for negotiation, bargaining, perhaps even re-drafting. The insurer examines the subject of the contract, the insured, before delivery, not after, as in casualty insurance. Here the insured signs a paper, not the policy, it is true, but an application which becomes a part of the policy. Hence, if the label "contract" in its classical sense is to fit any modern insurance transaction (other than re-insurance, reciprocal insurance, or the like where near equal bargainers are involved), life insurance would appear the most likely candidate.

\section{A. Formation of Contract: The Application for Life Insurance}

To trace the life cycle of a life insurance contract, one normally begins with the application. At this stage an investigation discloses two frequently recurring contract-formation situations which reveal unusual judicial attitudes. One is where the life insurance applicant dies while the company is still processing his application and it is charged that the company has unreasonably delayed approval. The other is where under similar circumstances it is alleged that the applicant was already "insured" because he had paid the first premium and received a "binding receipt" in return.

Professor Kessler has recently demonstrated that courts which have dealt with the first situation have been unable to agree as to who shall bear the risk of "loss without insurance" caused by the unreasonable delay of the insurer. ${ }^{23}$ Those courts which view the application as a "bare offer" imposing no liability on the company until it is accepted, cannot find the "acceptance" essential to recovery in contract, nor can they find the requisite consideration for an implied promise on the part of the company to act promptly, since the applicant is free to withdraw his offer at any time before acceptance and seek insurance elsewhere. Though there is an almost unanimous feeling ${ }^{24}$ against recovery in contract as "contrary to the well settled principles of contract law," the majority of courts still allow recovery by the "back door," so to speak, on a tort theory. The failure of the company to take prompt action is said to be tantamount to a breach of a general duty towards the

${ }^{23}$ Kessler, Contracts of Adhesion-Some Thoughts About Freedom of Contract, 43 CoL. L. Rivv. 629 (1943).

24 A few courts have based recovery on contract. E.g., Columbia Nat. Life Ins. Co. v. Lemmons, 96 Okla. 228, 222 Pac. 255 (1923). 
public to act without undue delay on applications involving acceptable risks. Kessler says that the courts which espouse this view ${ }^{25}$

are sure that the policy of insurance cannot be treated like any other contract. The state, by granting a franchise to the insurance company, by regulating and supervising its business, recognizes the great social importance of insurance business; it is, therefore, in the public interest that applications for acceptable risks shall not be unduly delayed. Thus the courts pay merely lip service to the dogma that the common law of contracts governs insurance contracts. With the help of the law of torts they nullify those parts of the law of contracts which in the public interest are regarded as inapplicable.

The second situation to reveal an unorthodox judicial attitude toward formation-of-contract principles centers around the legal consequences of prepayment of the first premium by a life insurance applicant who dies subsequent to the medical examination but prior to final approval. Gaunt v. John Hancock Mutual Life Insurance $\mathrm{Co}^{26}$ posed the problem to one of our most distinguished courts. The relevant facts were simple. On August 3, Gaunt signed a life insurance application and paid the soliciting agent the full first premium for which he received a receipt which read in part: "if the company is satisfied that on the date of the completion of [the medical part] of this application I was insurable and if this application [including the medical part] is, prior to my death, approved by the company at its Home Office, the insurance applied for shall be in force as of the date of completion of [the medical part]."2t On the same day the company's local examining physician found Gaunt insurable and recommended the risk for acceptance. After the company received satisfactory reports from several re-examinations of Gaunt made at its request, the medical department of the home office on August 26 approved the application from a medical standpoint. But the home office, having received word on the same day that Gaunt had been killed prior to this medical approval, refused to give the application final approval, though the trial judge found that if Gaunt had lived, it would have done so.

It was evident that the application was not finally approved at the home office "prior to" Gaunt's death. Nevertheless, Judge Learned Hand, speaking for the court, affirmed a judgment for Gaunt's beneficiary. Admitting that, literally read, the

${ }^{35} \mathrm{Id}$. at 635 . Kessler's incisive comment raises the question whether the insurance contract is "affected with a public interest." Ever since the landmark German Alliance Ins. Co. v. Kansas, 233 U. S. 389 (1914), it has been assumed almost without question that the insurance business, in its various ramifications, is "affected with a public interest." Justice McKenna, speaking for a bare majority, there recognized that insurance contracts had "greater public consequences than contracts between individuals to do or not to do a particular thing whose effect stops with the individual." $I d$. at 4 I3. There is no intimation, however, that the Court regarded "the insurance corporation as a public service company, under a legal duty to insure upon reasonable terms all properly qualified applicants-just as a railroad company is under a similar duty to furnish transportation," a point toward which, Patterson once suggested, the law might be tending. Patterson, supra note 10, at 216 . At most, the insurance business is a quasi-public utility, although as a constitutional matter, it is arguable that the states always had, and the federal government now has, the power to regard it as a full-fledged public utility, owing duties to the public as to the negotiation and writing as well as the pricing of its contracts.

${ }^{20}$ x60 F. 2 d 599 (2d Cir. 1947), 60 HARv. L. Rev. 1164 .

${ }^{27} I d$. at $599-600$. 
clause did not cover the insured if he died after completion of the medical part but before approval at the home office, Judge Hand searched the record for a rational quid pro quo which the insured might have received for having prepaid the first full premium. Unpersuaded by the company's recital of six incidental benefits, ${ }^{29}$ Judge Hand took the position that ${ }^{29}$

an underwriter might so understand the phrase, when read in its context, but the application was not to be submitted to underwriters; it was to go to persons utterly unacquainted with the niceties of life insurance, who would read it colloquially. It is the understanding of such persons that counts; and not one in a hundred would suppose that he would be covered not "as of the date of completion of [the medical part]," as the defendant promised, but only as of the date of approval. . . . the ordinary applicant who has paid his first premium and has successfully passed his physical examination, would not by the remotest chance understand the clause as leaving him uncovered until the insurer at its leisure approved the risk; he would assume that he was getting immediate coverage for his money... . A man must indeed read what he signs, and he is charged, if he does not; but insurers who seek to impose upon words of common speech an esoteric significance intelligible only to their craft, must bear the burden of any resulting confusion.

But Judge Clark, concurring, could not find this "confusion" in the company's forms of application and receipt. Between equal bargainers, the Judge noted, there was no question but that the insurance was not intended to take effect until the condition precedent of home office approval was met, and that it then dated back to an earlier time. Furthermore, was it not a little late for his experienced brethren (the two Hands) to "evince surprise" at a condition as widely used as this receipt form? Judge Clark favored the result, however, because the course of negotiations required and controlled by the insurance company was "unpardonable," but he would place the result squarely on the inequity of this kind of bargaining rather than upon a strained interpretation which "seems sure to produce continuing uncertainty in the law of insurance contracts." 30

Judge Clark doesn't spell out what was "unpardonable" in the course of negotiations between the applicant and the company. The facts as stated by Judge Hand include no representation by the soliciting agent that the insurance was to be effective from the moment Gaunt paid and the agent gave Gaunt a receipt for the first premium. Was it unpardonable for the company to take Gaunt's money and hand him a form receipt which deferred its liability until final approval of the application? Judge Clark may be sugggesting something of this sort. If so, he is attacking a basic method of selling life insurance employed by some of the leading

2a The six possible "advantages" to the insured were: "( $\mathrm{I}$ ) The policy would sooner become incontestable. (2) It would earlier reach maturity, with a corresponding acceleration of dividends and cash zurrender. (3) It would cover the period after approval and before issue. (4) If the insured became uninsurable between completion and approval, it would still cover the risk. (5) If the insured's birthday was between completion and approval, the premium would be computed at a lower rate. (6) When the policy covers disability, the coverage dates from completion." Id. at 6oI. It is fairly certain that in any other contract situation, these six advantages would satisfy any minimal thcory of consideration.

${ }^{20} 1 d$. at $601-602$.

${ }^{30} \mathrm{Jd}$, at 603 . 
life companies every day of the week, and presumably approved by the state insurance departments. What would Judge Clark consider an "equitable" course of dealing? Temporary coverage such as is given for fire and casualty insurance? But this would put the life insurer in a precarious position in the event the applicant was found to be uninsurable. No one will deny that the life insurer should have a reasonable time to investigate an application from both a medical and financial standpoint. But at the same time, the insurer would like to protect itself against an out-of-pocket loss for medical and investigation expenses in the event the applicant backs out. As Judge Clark points out, some companies obtain the desired result by making the insurance effective from the date of the medical examination if the insurer in its judgment shall be "satisfied" as to the insurability of the applicant on that date. Several writers have favored the "satisfaction" type receipt form as the more desirable business practice. ${ }^{31}$ Judge Clark would frankly redraft the contract to read in terms of this better practice because of the inequitable bargaining which occurred; Judge Hand would call the receipt form ambiguous and construe it against the draftsman under the strict construction rule. Either device, equitable or interpretative, leads to the single conclusion that in the formation of life insurance contracts, some judges will not be bound by classical rules of general contract.

\section{B. Performance: Aviation Risk Exclusion Clauses in World War II}

Performance in a life insurance contract, as compared with other types of insurance, is aleatory only in the sense that the time of the insured event is fortuitous, the event itself being as inevitable as taxes. For purposes of actuarial computation, the life insurer seeks to limit performance on the insured's death to normal, ascertainable risks; hence it rules out extra-hazardous occupations. Until recently, most companies attempted to rule out any participation in aviation as such an abnormal risk, not only in ordinary life policies but in their accidental death benefit and double indemnity provisions. The accent on aviation in the recent war resulted in a spate of opinions construing these aviation exceptions.

The aviation clause made its debut in the Twenties when participation in aviation was still a daredevil stunt. Some of the early clauses, which were clearly directed against any and all kinds of activity having to do with flying, were actually not put to the test until the late Thirties or Forties, by which time commercial aviation had become both customary and respectable. In 193r, the New York Court of Appeals was called upon in the Gibbs case ${ }^{32}$ to interpret a double indemnity clause "for death by accident, unless it should result from or be caused directly or indirectly by ' . . engaging as a passenger or otherwise in submarine or aeronautic expeditions." "33 The insured was killed while a passenger on a commercial flight. The

\footnotetext{
${ }^{31}$ See Havighurst, Life Insurance Binding Receipts, 33 ILL. L. REv. I80, 186 (1938); Comment, Operation of Binding Receipts in Life Insurance, 44 YALE L. J. 1223 (1935).

${ }^{32}$ Gibbs v. Equitable Life Assurance Society, 256 N. Y. 208, 176 N. E. 144 (1931).

${ }^{33}$ Id. at 209,176 N. E. at 144 .
} 
court, recognizing that in "x924, when this policy was written, submarines, airplanes, dirigibles, even balloons had not been developed to the condition in which they exist today,"34 decided the clause intended to exclude every aviation risk, even regularly scheduled commercial flights. A dozen years later, however, when the New York Court of Appeals in the Hartol Products case ${ }^{35}$ had to decide whether a x930 accidental death benefit clause (which excluded death resulting " 'from having been engaged in military or naval service in time of war; or in submarine operations or in aviation or aeronautics, as a passenger or otherwise ... '"') ${ }^{36}$ covered the insured who had been killed while a fare-paying passenger on a regularly scheduled flight over an established route, the beneficiary was permitted to recover the $\$ 50,000$ at stake. Though the clause read practically word for word like the one in the Gibbs case, this time the court found abundant ambiguity in the word "engaged" (particularly its use in an occupational sense in reference to military service and submarine operations, and in a different sense in reference to aviation). Appealing to a lay reaction to this "ambiguity," the majority asserted that the "average person applying for a policy would no more think of a passenger on an airplane as being engaged in aviation or aeronautics than he would think of a passenger on a railroad train as being engaged in railroading or a passenger on an ocean liner as being engaged in navigation." ${ }^{37}$ In order to distinguish the Gibbs case, the court quoted "passenger air mile" statistics for 930 to prove that a trip by air was not "uncommon for the average individual, was neither an extraordinary event nor accompanied by unusual hazards"38-a paraphrase of air travel in 1924 as described by the Gibbs court. The court saw nothing in the Gibbs opinion to foreclose "consideration of current changes in the common understanding of the ordinary everyday meaning of words and phrases which changing conditions of life over a lapse of time have effected." 39 The lapse of time, it should be noted, was only six years, and the court did not take the pains to quote "passenger air mile" statistics for $1924 .{ }^{40} \ldots$,

One would expect that the aviation risk clause would fare no better in the wartime aviation death cases. In the 1946 Clapper case, ${ }^{41}$ the circuit court for the District of Columbia construed a policy issued in 1928 providing for double indemnity "if the death of the insured occurs ... from bodily injuries effected solely through external, violent, and accidental means . . . [and] not . . . from an aeronautic flight ...,"42 to cover a situation where the insured, a famous correspondent, lost his

36 Id. at 210,176 N. E. at 145 .

${ }^{36}$ Hartol Products Corp. v. Prudential Insurance Co. of America, 290 N. Y. 44, 47 N. E. 2 d 687 (1943).

${ }_{30} I d$. at 46,47 N. E. $2 d$ at 689 .

${ }^{38} I d$. at $5 \mathrm{I}, 47$ N. E. $2 \mathrm{~d}$ at $69 \mathrm{r}$.

${ }^{37}$ Id. at 48,47 N. E. 2 d at $689-690$.

"2o Lehman, C. J., and Desmond, J., dissented on the ground that "by the clear and unambiguous language of the policy the accident was excluded from the coverage of the 'accidental death benefit provisions." "Ibid.

"On the general problem, see the exhaustive study by Glass, Aeronautic Risk Exclusion in Life Insurance Contracts, 7 J. Air L. 305, 560 (1936).

${ }^{11}$ Clapper v. Aetna Lifë Ins. Co., ${ }_{57}$ F. $2 d 7^{\circ}$ (D. C. Cir. 1946), 14 U. of Chr. L. Rev. 693 (r947).

${ }^{4}$ Clapper v. Aetna Life Ins. Co., supra. 
life while an invited guest-passenger on a naval fight in the Marshall Islands. Here, there was no justification for the court to bring the policy clause up to date, because it would not be within "common understanding," that such a clause covered a military flight at the time of insured's death any more than in 1928. Relying on Webster's New International Dictionary, the court suggested, however, that "aeronautic flight" had an occupational significance, and "even if this interpretation is subject to challenge, the same result would follow, since at best the phrase is so ambiguous as to compel a decision in favor of the insured."43 The decision is questionable on two counts: Was the phrase ambiguous? Even if so, would not a reasonable person expect it to exclude a military flight?

On its side the insurer had as an additional excuse in many of the World War II cases a war risk clause. But the availability of a war risk clause often turned out to be a two-edged weapon. For example, in the Schifter case, ${ }^{44}$ where in one clause the policy expressly excluded war-time military and naval service but by a later endorsement covered continental war service, and the insured was killed in a state-side training flight, admittedly excluded by the aviation risk clause, the New York court held the insured covered by the endorsement which spoke of all kinds of continental military service. Because of the internal contradiction, the result here seems reasonable. It does not, however, in the Conaway case ${ }^{45}$ where the failure of the insurer to insert in the policy proper a war risk clause while incorporating it in the double indemnity clause led the Ohio Supreme Court to draw the negative inference that the insurer did not intend its aviation risk clause to apply where the insured had met his death while piloting a military craft on a military mission. Though war was imminent when the insured applied for the policy, the majority interpreted the phrase in the policy "on account of the aviation hazard of the insured" to read "civilian aviation hazard" and accordingly gave judgment for the beneficiary. ${ }^{46}$ Even if war was not imminent, one wonders whether a reasonable man would not perceive that an insurance company concerned with the risks incident to civil aviation would a fortiori be concerned with the risk incident to military aviation.

If the above cases can be considered at all typical, the courts seem here, as compared with their treatment of the formation-of-contract cases, to have done more than balance the scales in favor of the insured's reasonable expectations. Perhaps the results suggest the extremes to which the "interpretative device" can be put, once it becomes accepted as a tool of judicial construction.

${ }^{4}$ Id. at 77.

“Schifter v. Commercial Travelers Mutual Accident Ass'n of America, 183 Misc. 74, 50 N. Y. S. 2d 376 (Sup. Ct. r944).

${ }^{48}$ Conaway v. The Life Insurance Co. of Virginia, 148 Ohio St. 598,76 N. E. 2 d 284 (1947) (three judges dissented).

${ }^{40} \mathrm{Sec}$ also Quinones v. Life \& Casualty Insurance Co. of Tennessee, 209 La. 76, 24 So. 2d 270 (1945), where the aviation rider in the usual form covering fare-paying flights only was held to cover a routine military flight. 
C. Discharge: Settlement Practices

A third stage open to possible investigation in the life cycle of a life policy presents itself after the death of the insured when the insurer attempts to "settle" with the beneficiary. Kellogg v. Iowa State Traveling Men's Ass'n, ${ }^{47}$ a 1947 Iowa decision, suggests that the classical contract rule of accord and satisfaction may be by-passed where a court concludes the insurer has been over-reaching in making a quick settlement with the beneficiary. In the Kellogg case the defendant insurer, a fraternal association, refused to pay the plaintiff beneficiary the full $\$ 5,000$ in the membership certificate on the ground that the insured's death, which occurred within an hour after a highway collision, had been "effected or aggravated by heart disease," in which event the insurer's liability was limited to ro per cent, or $\$ 500$, a check for which the company had sent the plaintiff in full settlement, and which check plaintiff had cashed. Though it is arguable that there was not an effective accord and satisfaction because the part payment was not tendered in satisfaction of a disputed or unliquidated claim and thus came within the prohibition of Foakes $v$. Beer, ${ }^{48}$ the Iowa Supreme Court stressed at some length that this was a situation "where the relationship between the parties is closely akin to a fiduciary one, and where the insurer should be most meticulous and conscientiously scrupulous to protect the rights of the beneficiary and to give every opportunity to fully establish her rights." ${ }^{49}$ The spokesman for the three dissenting judges did not let the opportunity pass to point out that no authority was cited for this novel theory of fiduciary relationship which undercut the traditional assumption that "the parties were dealing at 'arm's length.' Defendant owed to the beneficiary the duty it would owe to any other person with whom it dealt-the duty to deal uprightly."50 In effect, the dissenters did not see that the "settlement" in this case differed from one between a grocer and his debtor.

The Kellogg case carries recognition of the inequality of the bargaining power of the parties beyond the negotiation stage over into the final settlement stage. In so doing it makes orthodox contract notions such as accord and satisfaction burst at the seams. Life insurance, of course, is not the only kind of one-sided transaction which has recently been subjected to the same kind of judicial treatment, as witness the railroad release cases. ${ }^{51}$

\section{III}

\section{Legislattve Concern with the Insurance Contract}

If, as the recent cases seem to indicate, the judges have such difficulty squaring the general principles of contract law with the facts of insurance life, one might

${ }^{47}$ Kellogg v. Iowa State Traveling Men's Ass'n, 239 Iowa I96, 29 N. W. 2 d 559 (x947), I6 U. op CHI. L. Rev. 177 (1948).

18 App. Cas. 605 (1884).

${ }^{4}$ Kellogg v. Iowa State Traveling Men's Ass'n, 239 Iowa 196, 2r3, 29 N. W. 559, 568 (r947).

${ }^{50} I d$. at 232,29 N. W. $2 \mathrm{~d}$ at 578 .

${ }^{51}$ See Frank, J., concurring in Ricketts v. Pennsylvania R. R., I53 F. 2d 757, 760 (2d Cir. I946); of. Callen v. Pennsylvania R. R., 332 U. S. 625 (1948). 
expect the legislators to have stepped into the breach. Unquestionably, the legislatures have been pressured into much remedial action in the last few decades, such as the development of the 1943 New York standard fire policy, the statutes converting strict warranties into representations, and the requirement of standard provisions in life policies. It is also true that both the life and fire insurance industries have recently been subjected to public scrutiny, the former in the 1940 TNEC investigation, ${ }^{52}$ the latter in the Congressional hearings ${ }^{53}$ before and after the 1944 South-Eastern Underwriters decision. ${ }^{54}$ The TNEC investigation was mainly concerned with the impact on the economy of life insurance company investment policy; the Congressional hearings on the South-Eastern case with monopolistic practices in the fixing of fire insurance rates. While the TNEC investigation directly attacked the problem of the relationships between insurer and insured in regard to agency practices and industrial insurance, ${ }^{55}$ at no point was there a consideration of the basic nature of the insurance contract. The closest approach to the problem was one of the TNEC final recommendations that "the number of policy forms should be reduced and greater attention given to establishing standardized policy forms or policy provisions acceptable in all states. The present confusion in this field is most undesirable." Sumner Pike in summarizing the investigation, pointed out that "we have ... one or two of the [life] companies that had over 130 technically different forms of policy which could be presented."

\section{IV}

\section{Legal Writing on the Insurance Contract}

The judges, as I have indicated, have not been able to meet the challenge of the standardized life insurance contract largely because of the piecemeal fashion in which the problem has arisen in the litigated cases. The legislators, on their part, have recently been more concerned with the investment and price-fixing aspects of the problem than with its contractual side. One might expect that the legal writers, who occupy a relatively objective position, would have delved into the problem and come up with some recommendations directed toward either a legislative or judicial change of policy. It is surprising, therefore, to find a real dearth of American legal literature on the insurance contract qua standardized contract. There is nothing, for instance, comparable to Prausnitz's pioneering study of English and continental

\footnotetext{
:2 Sec Gesell and Howe, Study of Legal Reserve Life Insurance Companies (TNEC Monograph 28, 1940).

${ }^{63}$ See Joint Hearings before Subcommittees of the Committees on the Judiciary on S. ${ }_{3} \sigma_{2}, H . R$. 3269, and H. R. 3270, 78th Cong., Ist \& 2 d Sess. (1943-1944.)

s4 United States v. South-Eastern Underwriters Ass'n, 322 U. S. 533 (I944) (declaring insurance in interstate commerce).

${ }^{55}$ GeSELl AND Howe, op. cit. supra note $52, \S \S \mathrm{XV}$, XVI.

TNEC, Final Reports and Recommendations, Sen. Doc. No. 35, 77th Cong., ist Scss. 42 (1941).

${ }^{87} I d$. at 567 . As to industrial insurance, Mr. Pike said: "The number of policy forms available and variations in policy provisions are highly undesirable and conducive to misrepresentation and misunderstanding on the part of the policyholder." Id. at 598 .
} 
standardized contracts. ${ }^{58}$ Cohen, Isaacs, and Llewellyn have probed the standardized contract in general, ${ }^{59}$ Llewellyn's review of Prausnitz's book being one of the most incisive short statements of the problem extant. ${ }^{60}$ Recently, Kessler has contributed a brilliant essay on the standardized contract and freedom of contract, with special reference to the insurance contract. ${ }^{61}$ Some of the best thinking on standardized contracts in general has, and this should come as no surprise, appeared in the student sections of the law reviews. ${ }^{62}$ But nowhere has there been a serious, full dress attempt to re-define the modern American insurance transaction as a sui generis matter.

Perhaps the job is too big, or too dull. Admittedly, the volume of case law is overwhelming. In 1944-a war year-the reporter on insurance for the New York University Annual Survey examined 600 appellate decisions, ${ }^{63}$ only a part of the "flood of reported decisions ... growing more unmanageable every year," to stem which the late Sidney Post Simpson whimsically suggested a "moratorium on law reporting until legal thinking catches up with the writing of judicial opinions." ${ }^{\text {.64 }}$

\section{$\mathrm{V}$}

\section{SUgGestrons For Further StudY}

If the legal writers-who occupy the enviable position of sitting on the sidelines and watching the lawyers, judges, legislators, and administrators "operate" the insurance transaction-were to make a serious effort to re-examine the special nature of the insurance contract, where would they begin?

First, an exhaustive study of the recent volume of case law would enable one to determine whether the tentative hypothesis this paper suggests-that there is developing a separate body of insurance contract law which has little relation to the "general principles of contract law"-can be accepted as an established proposition. Such a study may reveal that the courts are creating hosts of special rules, only a few of which have been mentioned in the preceding paragraphs, to handle insurance cases within the framework of general contract law.

If this proposition as to the sui generis nature of insurance law was established, the next step would be an examination of the consequences for both insured and insurer. Do the special rules of construction enable the insured to obtain his reasonable expectations and to satisfy his insurance needs? At what cost does he


LAw (1937).

${ }^{10}$ See, e.g., Cohen, The Basis of Contract, 46 Harv. L. Rev. 553 (1933); Isaacs, The Standardizing of Contracts, 27 Yale L. J. 34 (1917); Llewellyn, What Price Contract?-An Essay in Perspective, 40 YALE L. J. 704 (I93I).

co Llewellyn, Book Review, 52 Harv. L. REv. 700 (1939).

${ }^{2}$ See note 23 supra.

${ }^{02}$ See, e.g., Note, Contract Clatuses in Fine Print, 63 Harv. L. Rev. 494 (1950); Note, Private Latvmaking by Trade Associations, 62 Harv. L. Rev. 1346 (1949); Note, Grower-Canner Agreements: An Abusc of Mass Standardized Contracts, 58 YaLE L. J. II6I (1949).

ais MeKenna, Insurance in 1944 Annual Survey of American Law 784.

os Simpson, Equity in 1946 id. at 879 . 
succeed in such litigation? (Does he lose a large part because of the customary contingent fee arrangement?) What percentage of "litigatable" cases are settled by the insurer? How big a discount must the insured take in the course of such settlement? Is the value of the insurance as "security" (particularly life) impaired because of the shadow of litigation and the possibility of an adverse decision by a hard-nosed court? On the other hand, from the insurer's standpoint, what are the consequences? How high a contingent reserve must insurers keep for satisfying judgments based on the unpredictable "ambiguities" which courts "discover." How much of a reserve must be kept for similar cases which the insurer decides to settle? How costly is this whole procedure? Do the insurers pass this cost on to the insureds in higher premium rates?

If the consequences added up to a highly undesirable state of affairs for both insured and insurer, one might next consider alternative remedies. First, with respect to the system as it now operates, what could be done to improve judicial administration of insurance protection? Would a frank recognition of the facts of insurance life by the judges help? Undoubtedly, Judge Clark's candid suggestion that courts decide the hardship cases on equitable grounds, rather than strained interpretation, would better preserve the symmetry of the law, but would it avoid the evil consequences of insecurity and expense for both insured and insurer? Next, if it is assumed that the courts are incapable of solving the problem through common law theories as presently buttressed with insurance legislation, is more legislation the answer? Would it be possible to draft a uniform insurance code which would offer a wide choice of standardized policies to the insured, each approved in terms of conformity with the reasonable expectations and needs of the insureds? (To meet the insurer's practical objection that it competes in the market on a "special feature," rather than on a price basis, the alternatives in each class of insurance might be limited only if "unfair" to the insurance buyer.) Finally, should the administration of a quasi-public utility such as insurance be taken out of the courts and placed into the hands of an administrative agency? What have been the consequences of state administration of workmen's compensation? Would a state agency be subjected to the same kind of pressure state public service commissions often succumb to, or to put it conversely, are not the courts better guardians of the interests of the weaker party to a one-sided bargain? (Would it continue to be a one-sided bargain if the legislature was actually to act on behalf of the public in standardizing policies?)

This article might have been sub-titled: "Reflections on Reading Some Recent Insurance Cases." Like most reflections, these are subject to criticism for incompleteness; to become "observations" they require a kind of consideration which lay outside the scope of this symposium. But, while not the basis for action, these reflections strongly suggest the need for further research and thought as to the special nature of the insurance contract, if the expectations of all parties to the transactionthe insured, the company, the beneficiaries, and all who claim thereby-are to be protected adequately. 